\title{
CONTENT AND UPTAKE OF MICROELEMENTS (CU, ZN, MN, FE) BY MAIZE (Zea mays L.) AND ACCOMPANYING WEEDS
}

\author{
Aleksandra Głowacka \\ University of Life Sciences in Lublin, Faculty of Agricultural Sciences in Zamość, Szczebrzeska 102, 22-400 Zamość, Poland \\ e-mail: aleksandra.glowacka@up.lublin.pl
}

Received: 02.02.2012

\begin{abstract}
A field experiment was conducted in the years 20082010 at the Research Station of the Faculty of Agricultural Sciences, University of Life Sciences in Lublin, on brown soil with slightly acidic $\mathrm{pH}$ and average abundance of copper, zinc, manganese, and iron. The experiment was set up in a randomized split-plot design with four replications, with two methods for controlling weed infestation: I. mechanical - weeding of inter-rows twice; II. chemical - the herbicide Afalon Dyspersyjny $450 \mathrm{SC}$, directly after sowing (a.i. linuron, $900 \mathrm{~g} \times \mathrm{ha}^{-1}$ ).

Next, the copper, zinc, manganese and iron content were determined in the maize and dominant weed species. Nutrient uptake from an area of 1 ha and the species specificity coefficient (SSC) were also calculated. All the weed species examined contained more copper in their biomass than maize, but their percentage share in total uptake was small, on average $1.7 \%$. The content of zinc in maize biomass and in the segetal species was similar, except for Cirsium arvense L. which accumulated considerably less zinc than maize as well as the other weed species. The percentage share of weeds in zinc uptake was only $1.4 \%$ of total uptake of this nutrient by the maize crop. Competitiveness of weeds in the accumulation of manganese and iron showed high species specificity. Chenopodium album L. and Galinsoga parviflora Cav. were the most competitive in accumulating manganese, while Cirsium arvense L. showed high ability to accumulate iron, considerably much higher than maize and other weeds species. The share of weeds in total manganese uptake was relatively large, on average $7.2 \%$ for the experiment.
\end{abstract}

Key words: Zea mays L., weed control, copper, zinc, manganese, iron, uptake

\section{INTRODUCTION}

Mineral content in the plant depends primarily on the nature of the soil environment and biological proprieties of the species. Cultivated plants and weeds, growing side by side and competing for factors necessary for growth and development, exhibit differences in response depending on the subject of competition and habitat conditions (P a r y l a k, 1996). A different content of a specific nutrient in plants, growing in the same location or habitat, indicates their unequal ability to use soil resources (O św it and S a p e k, 1982). Weeds, as inseparable elements of agrocenoses, compete with crop plants not only for place, light, and water, but also for mineral nutrients.

The competitiveness of weeds in the uptake of nutrients and their mineral composition depend on the species and its development stage, degree of weed infestation, abundance of available forms of nutrients in the habitat, and the use of agricultural practices (Duer, 1986; Q a sem and Hil1, 1995; Y in et al. 2006; Trąba and Wiater, 2007; R og óż and $\mathrm{N}$ i e mi e c, 2010). The pattern of weather conditions is also not without significance. Dzida et al. (2004) reported that weed species such as Capsella bursa-pastoris (L.) Medik, Chenopodium album L., Elymus repens (L.) Gould, Plantago maior (L.) S. Str., Stellaria media L. Vill, Taraxacum officinale Web., and Urtica dioica L. are more competitive in the uptake of zinc than barley. However, in the case of copper only Plantago maior and Taraxacum officinale were characterized by higher microelement accumulation capability. P a r y la k and Z a w i e ja (2004) showed the influence of crop density on the competitiveness of Avena fatua L. to spring barley in the uptake of micronutrients, which was higher only under thinned crop conditions. Also $\mathrm{Malicki}$ and $\mathrm{Berbecio-}$ w a (1986) point to the impact of weed species and the crop in which it occurs on changes micronutrient content in their biomass.

The aim of the study was to determine the content of microelements - copper, zinc, manganese, and 
iron - in maize and in weeds dominant in its cultivation as well as the magnitude of uptake of these nutrients in the biomass of maize and weeds under conditions of mechanical and chemical methods of weed control.

\section{MATERIALS AND METHODS}

A field experiment was carried out in the years 2008-2010 at the Research Station of the Faculty of Agricultural Sciences in Zamość (50 $\left.42^{\circ} \mathrm{N}, 2^{\circ}{ }^{\circ} 16^{\prime} \mathrm{E}\right)$, University of Life Sciences in Lublin, on brown soil with slightly acidic $\mathrm{pH}(\mathrm{pH} 1 \mathrm{n} \mathrm{KCl}-6.2)$ and an average content of available forms of microelements, i.e. copper $-5.1 \mathrm{mg} \times \mathrm{kg}^{-1}$, zinc $-12.9 \mathrm{mg} \times \mathrm{kg}^{-1}$, iron $1005 \mathrm{mg} \times \mathrm{kg}^{-1}$, and manganese $-208 \mathrm{mg} \times \mathrm{kg}^{-1}$. Dent maize, 'Celio', was grown in a site where spring barley had previously been cultivated. This is a medium early variety (FAO 250), with the type of grain semident/ dent. The experiment was set up in a randomized split-plot design with four replications, with two weed control methods: I. mechanical - weeding of inter-rows twice (the first time at the 5-6 leaf stage of maize and again two weeks later); II. chemical - the herbicide Afalon Dyspersyjny 450 SC immediately after sowing (a.i. linuron, $900 \mathrm{~g} \times \mathrm{ha}^{-1}$ ).

The mineral fertilizer was applied uniformly in the following amounts: $\mathrm{N}-140 \mathrm{~kg} \times \mathrm{ha}^{-1}$ (ammonium nitrate), $\mathrm{P}-35 \mathrm{~kg} \times \mathrm{ha}^{-1}$ (triple superphosphate), $\mathrm{K}-100 \mathrm{~kg} \times \mathrm{ha}^{-1}$ (potassium chloride). Phosphorus and potassium fertilization was applied once, before spring pre-sowing treatments, while the application of nitrogen was split [half before sowing and half for top dressing at the 5-6 leaf stage of maize (BBCH 15/16)]. Maize was sown on 28 April, 4 May, and 10 May, at $65 \mathrm{~cm}$ row spacing using a one-row hand seeder. 10 rows of maize were seeded in the plot. There were 110,000 plants sown per hectare. Mechanical weed control was carried out using hand hoes with a working width of $38 \mathrm{~cm}$. The first weeding of the inter-rows was done to a depth of $5 \mathrm{~cm}$, while the second one to a depth of $3 \mathrm{~cm}$. Tillage was conducted according to the recommendations for maize.

The maize was harvested at the early dough stage (BBCH 79/83). After harvesting, dry weight yield was calculated per hectare. Two weeks before harvest, weeds were collected from $1 \mathrm{~m}^{2}$ of each plot (two sampling areas of $0.5 \mathrm{~m}^{2}$ each). The majority of weeds were at the blooming stage or after blooming. Determinations were made of their number and botanical composition, after which they were air-dried and the dry weight of the above-ground parts of particular species was determined as well as their total biomass. Next, copper, zinc, iron and manganese content were determined in the maize and in the dominant weed species, i.e. Chenopodium album L. (White Goosefoot), Galinsoga parviflora Cav. (Gallant Soldier), Echinochloa crus-galli (L.) P. Beauv. (Barnyardgrass), Cirsium arvense L. (Creeping Thistle), and Polygonum lapathifolium L. subsp. lapathifolium (Curlytop Knotweed), following mineralization by flame atomic absorption spectrometry (PN-EN ISO 68 69: 2002). The data on the number and weight of weeds are given in Table 1. The results for maize and weed biomass were discussed in an earlier paper ( $\mathrm{G}$ ło w a c k a , 2011). Based on the dry weight yield of maize and the biomass of particular weed species, nutrient uptake from an area of 1 ha was calculated. The species specificity coefficient (SSC) was also determined. It expresses the ratio of the content of a given mineral nutrient in the plant tested to the mean content in all the species tested in the plant community (L a m b e r t et al. 1973). A value of SSC $>1$ indicates high accumulation of a given element by the species. The results of the study were analysed statistically by calculating coefficients of variation and Pearson's linear correlation coefficients.

Table 1

Number and above-ground dry weight of weeds in maize before harvest and maize biomass depending on the weed control method (mean for 2008-2010) (G tow a cka, 2011)

\begin{tabular}{|c|c|c|c|c|c|c|}
\hline \multirow{2}{*}{ Weed species } & \multicolumn{3}{|c|}{ Number $\left(\right.$ no. $\left.\times \mathrm{m}^{-2}\right)$} & \multicolumn{3}{|c|}{ Dry weight $\left(\mathrm{g} \times \mathrm{m}^{-2}\right)$} \\
\hline & $\mathrm{I}^{*}$ & II & Mean & I & II & Mean \\
\hline Total & 35.6 & 19.4 & 27.5 & 148.1 & 90.2 & 119.2 \\
\hline Echinochloa crus-galli (L.) P. Beauv & 18.0 & 10.3 & 14.2 & 100.3 & 72.3 & 86.3 \\
\hline Galinsoga parviflora Cav. & 3.6 & 1.4 & 2.5 & 5.7 & 0.7 & 3,2 \\
\hline Chenopodium album $\mathrm{L}$. & 5.0 & 2.7 & 3.8 & 30.2 & 9.4 & 19.8 \\
\hline Cirsium arvense $\mathrm{L}$. & 2.0 & 1.0 & 1.5 & 2.9 & 0.9 & 1.9 \\
\hline Polygonum lapathifolium L. subsp. lapathifolium & 2.0 & 1.0 & 1.5 & 0.7 & 2.4 & 1.6 \\
\hline Others & 5.6 & 3.0 & 4.3 & 8.3 & 4.5 & 6.4 \\
\hline Maize biomass (tonnes d.w. per hectare) & & & & 9.6 & 11.6 & 10.6 \\
\hline
\end{tabular}

Explanation: *methods of weed control I - mechanical, II - chemical 


\section{RESULTS}

All the examined dominant weed species had higher copper content in their biomass than maize (Table 2). Among the weeds, the lowest content of $\mathrm{Cu}$ was found in Chenopodium album L. $-8.39 \mathrm{mg} \times \mathrm{kg}^{-1} \mathrm{~d} . \mathrm{w}$. (dry weight). Other weed species had higher contents of this micronutrient, but the differences among them were small, which confirms the low value of the coefficient of variation. In the case of both maize and segetal species, the applied weed control methods did not significantly influence the content of copper.

Table 2

Content of copper in above-ground parts of dominant weed species and maize and its uptake by plants depending on the weed control method (mean for 2008-2010)

\begin{tabular}{|c|c|c|c|c|c|c|}
\hline \multirow{3}{*}{ Species } & \multicolumn{6}{|c|}{ Copper } \\
\hline & \multicolumn{3}{|c|}{ Content $\left(\mathrm{mg} \times \mathrm{kg}^{-1}\right.$ d.w. $)$} & \multicolumn{3}{|c|}{ Uptake $\left(\mathrm{mg} \times \mathrm{ha}^{-1}\right)$} \\
\hline & $I^{*}$ & II & Mean & $I^{*}$ & II & Mean \\
\hline Echinochloa crus-galli (L.) P. Beauv & 10.3 & 10.5 & 10.4 & 1030.0 & 730.0 & 880.0 \\
\hline Galinsoga parviflora Cav. & 10.4 & 10.1 & 10.2 & 60.0 & 10.0 & 40.0 \\
\hline Chenopodium album $\mathrm{L}$. & 8.3 & 8.5 & 8.4 & 250.0 & 80.0 & 160.0 \\
\hline Cirsium arvense $\mathrm{L}$. & 10.1 & 9.8 & 9.9 & 30.0 & 30.0 & 10.0 \\
\hline Polygonum lapathifolium L. subsp. lapathifolium & 9.5 & 10.0 & 9.7 & 10.0 & 10.0 & 30.0 \\
\hline Zea mays $\mathrm{L}$. & 6.9 & 6.0 & 6.5 & 66400 & 69800 & 68100 \\
\hline Coefficients of variation $(\%)$ & 14.9 & 18.8 & 16.5 & 239 & 241 & 240 \\
\hline
\end{tabular}

Explanation: *methods of weed control: I - mechanical, II - chemical

Among the group of weed species tested, Polygonum lapathifolium L. subsp. lapathifolium had the highest zinc content in its biomass and it was higher than in the biomass of maize (Table 3). Chenopodium album L., Echinochloa crus-galli (L.) P. Beauv. and Galinsoga parviflora Cav. had a similar zinc content as maize. However, Cirsium arvense L. accumulated much less of this micronutrient compared to maize and the other weed species. The maize from the plots where chemical weed control methods were applied contained significantly less $\mathrm{Zn}$ than that from the sites where only the mechanical method was used.

Table 3

Content of zinc in above-ground parts of dominant weed species and maize and its uptake by plants depending on the weed control method (mean for 2008-2010)

\begin{tabular}{|c|c|c|c|c|c|c|}
\hline \multirow{3}{*}{ Species } & \multicolumn{6}{|c|}{ Zinc } \\
\hline & \multicolumn{3}{|c|}{ Content $\left(\mathrm{mg} \times \mathrm{kg}^{-1}\right.$ d.w. $)$} & \multicolumn{3}{|c|}{ Uptake $\left(\mathrm{mg} \times \mathrm{ha}^{-1}\right)$} \\
\hline & $I^{*}$ & II & Mean & $I^{*}$ & II & Mean \\
\hline Echinochloa crus-galli (L.) P. Beauv & 23.9 & 24.4 & 24.1 & 240.0 & 174.0 & 207.0 \\
\hline Galinsoga parviflora Cav. & 25.0 & 24.2 & 24.6 & 140.0 & 20.0 & 80.0 \\
\hline Chenopodium album $\mathrm{L}$. & 24.8 & 23.7 & 24.2 & 750.0 & 220.0 & 470.0 \\
\hline Cirsium arvense $\mathrm{L}$. & 16.5 & 16.9 & 16.7 & 50.0 & 20.0 & 40.0 \\
\hline Polygonum lapathifolium L. subsp. lapathifolium & 26.5 & 25.8 & 26.1 & 20.0 & 60.0 & 40.0 \\
\hline Zea mays $\mathrm{L}$. & 24.3 & 14.5 & 19.4 & 233.3 & 168.2 & 200.7 \\
\hline Coefficients of variation (\%) & 15.1 & 21.6 & 18.4 & 240.8 & 241.4 & 241.1 \\
\hline
\end{tabular}

Explanation: *methods of weed control: I - mechanical, II - chemical

The manganese content in the dominant weed species was several times higher than in maize (Table 4). Cirsium arvense L., which accumulated the least amount of Mn among the weeds, had 4 times higher content of manganese than maize. The highest concentration of this element was found in Galinsoga parviflora
Cav. and Chenopodium album L. and it was 10 times higher than in maize biomass. Considerable variation in the content of $\mathrm{Mn}$ among the investigated species is confirmed by the high coefficient of variation. The weed control methods did not affect significantly the changes in manganese content in the studied plants. 
Table 4

Content of manganese in above-ground parts of dominant weed species

and maize and its uptake by plants depending on the weed control method (mean for 2008-2010)

\begin{tabular}{|c|c|c|c|c|c|c|}
\hline \multirow{3}{*}{ Species } & \multicolumn{6}{|c|}{ Manganese } \\
\hline & \multicolumn{3}{|c|}{ Content $\left(\mathrm{mg} \times \mathrm{kg}^{-1}\right.$ d.w. $)$} & \multicolumn{3}{|c|}{ Uptake $\left(\mathrm{mg} \times \mathrm{ha}^{-1}\right)$} \\
\hline & $\mathrm{I}^{*}$ & II & Mean & $\mathrm{I}^{*}$ & II & Mean \\
\hline Echinochloa crus-galli (L.) P. Beauv & 72.4 & 71.3 & 88.4 & 7260.0 & 5150.0 & 6490.0 \\
\hline Galinsoga parviflora Cav. & 101.0 & 104.3 & 102.7 & 580.0 & 70.0 & 330.0 \\
\hline Chenopodium album $\mathrm{L}$. & 102.0 & 103.0 & 102.5 & 3080 & 980.0 & 2030.0 \\
\hline Cirsium arvense $\mathrm{L}$. & 42.2 & 43.5 & 42.8 & 120.0 & 40.0 & 80.0 \\
\hline Polygonum lapathifolium L. subsp. lapathifolium & 58.4 & 59.0 & 58.7 & 40.0 & 140.0 & 90.0 \\
\hline Zea mays $\mathrm{L}$. & 10.7 & 11.0 & 10.9 & 102700.0 & 127600.0 & 115200.0 \\
\hline Coefficients of variation (\%) & 54.8 & 54.9 & 54.8 & 216.8 & 231.1 & 224.0 \\
\hline
\end{tabular}

Explanation: *methods of weed control: I - mechanical, II - chemical

The concentration of iron in Chenopodium album L. and Polygonum lapathifolium L. subsp. lapathifolium was lower than in fodder maize, whereas $\mathrm{Ga}$ linsoga parviflora Cav. and Echinochloa crus-galli (L.) P. Beauv accumulated more of this element (Table 5). Cirsium arvense $\mathrm{L}$. was a species that accumulated a lot of $\mathrm{Fe}$; in its biomass, it contained 4 times more of this microelement than maize and much more than the other weed species studied. The value of the coefficient of variation for Fe was the highest among the examined micronutrients.

Table 5

Content of iron in above-ground parts of dominant weed species

and maize and its uptake by plants depending on the weed control method (mean for 2008-2010)

\begin{tabular}{|c|c|c|c|c|c|c|}
\hline \multirow{3}{*}{ Species } & \multicolumn{6}{|c|}{ Iron } \\
\hline & \multicolumn{3}{|c|}{ Content $\left(\mathrm{mg} \times \mathrm{kg}^{-1}\right.$ d.w. $)$} & \multicolumn{3}{|c|}{ Uptake $\left(\mathrm{mg} \times \mathrm{ha}^{-1}\right)$} \\
\hline & $I^{*}$ & II & Mean & $I^{*}$ & II & Mean \\
\hline Echinochloa crus-galli (L.) P. Beauv & 109.0 & 107.0 & 10.1 & 10930.0 & 7740.0 & 9340.0 \\
\hline Galinsoga parviflora Cav. & 85.1 & 85.9 & 85.5 & 490.0 & 60.0 & 280.0 \\
\hline Chenopodium album $\mathrm{L}$. & 57.6 & 58.2 & 57.9 & 1740.0 & 550.0 & 1150.0 \\
\hline Cirsium arvense $\mathrm{L}$. & 249.0 & 253.0 & 251.0 & 720.0 & 220.0 & 470.0 \\
\hline Polygonum lapathifolium L. subsp. lapathifolium & 58.6 & 59.3 & 58.9 & 40.0 & 140.0 & 90.0 \\
\hline Zea mays $\mathrm{L}$. & 67.4 & 54.6 & 61.0 & 647040.0 & 633360.0 & 640200.0 \\
\hline Coefficients of variation $(\%)$ & 70.3 & 74.0 & 72.2 & 238.8 & 241.0 & 240.0 \\
\hline
\end{tabular}

Explanation: *methods of weed control: I - mechanical, II - chemical

The amount of micronutrients taken up from the soil was mainly the result of the quantity of biomass produced by the crop plant and its accompanying weeds, which confirms the value of the linear correlation coefficient for, respectively: $\mathrm{Cu}-\mathrm{r}=0.997 ; \mathrm{Mn}-$ $\mathrm{r}=0.998 ; \mathrm{Fe}-\mathrm{r}=0.993 ;$ and $\mathrm{Zn}-\mathrm{r}=0.961(\mathrm{n}=24$, $\mathrm{p}<0.01)$. Maize yield was on average $10.6 \mathrm{t} \times \mathrm{ha}^{-1} \mathrm{~d} . \mathrm{w}$. per hectare, and total weed biomass $0.23 \mathrm{t} \times$ ha $^{-1} \mathrm{~d}$.w., hence the differences in the uptake of elements were significant. The percentage of weeds in total copper uptake from the soil was $2.0 \%$ for mechanical weed control and $1.3 \%$ for the chemical method (Fig. 1).

A negative correlation was shown between $\mathrm{Cu}$ content in plants and total uptake $(r=-0.743)$. Total zinc uptake in plant biomass of the maize crop was $236600 \mathrm{mg} \times \mathrm{ha}^{-1}$ in the plots where mechanical weed control was applied, while the percentage of weeds in total uptake was only $1.4 \%$ and $170300 \mathrm{mg} \times \mathrm{ha}^{-1}$ in the case of chemical weed control; and the percentage of weeds in total uptake was slightly lower and accounted for 1.2\% (Fig. 1). Among the weed species tested, the highest amount of copper and zinc was taken up by Echinochloa crus-galli (L.) P. Beauv., regardless of weed control methods applied (Tables 2 and 3 ). Total uptake of manganese in plant biomass (maize + weeds) was $113800 \mathrm{mg} \times \mathrm{ha}^{-1}$ and $136300 \mathrm{mg} \times \mathrm{ha}^{-1}$, while the share of weeds in uptake was $9.7 \%$ and $4.8 \%$ for mechanical and chemical weed control methods, re- 
spectively (Fig. 2). Echinochloa crus-galli (L.) P. Beauv. took up the largest amount $\mathrm{Mn}$, because of its high biomass production. A considerable amount of this micronutrient, in comparison with other species, was also taken up by Chenopodium album L. (Table 4).

As in the case of $\mathrm{Cu}$, the amount of Mn uptake was also negatively correlated with its content in plants $(r=-0.649)$. Among all analyzed trace elements, iron was the element taken up by the maize crop at the highest amount - on average $640000 \mathrm{mg} \times \mathrm{ha}^{-1}$. The percentage of weeds in iron uptake was much smaller than for manganese and amounted to $2.1 \%$ and $1.4 \%$, respectively, for the mechanical and chemical weed control methods.

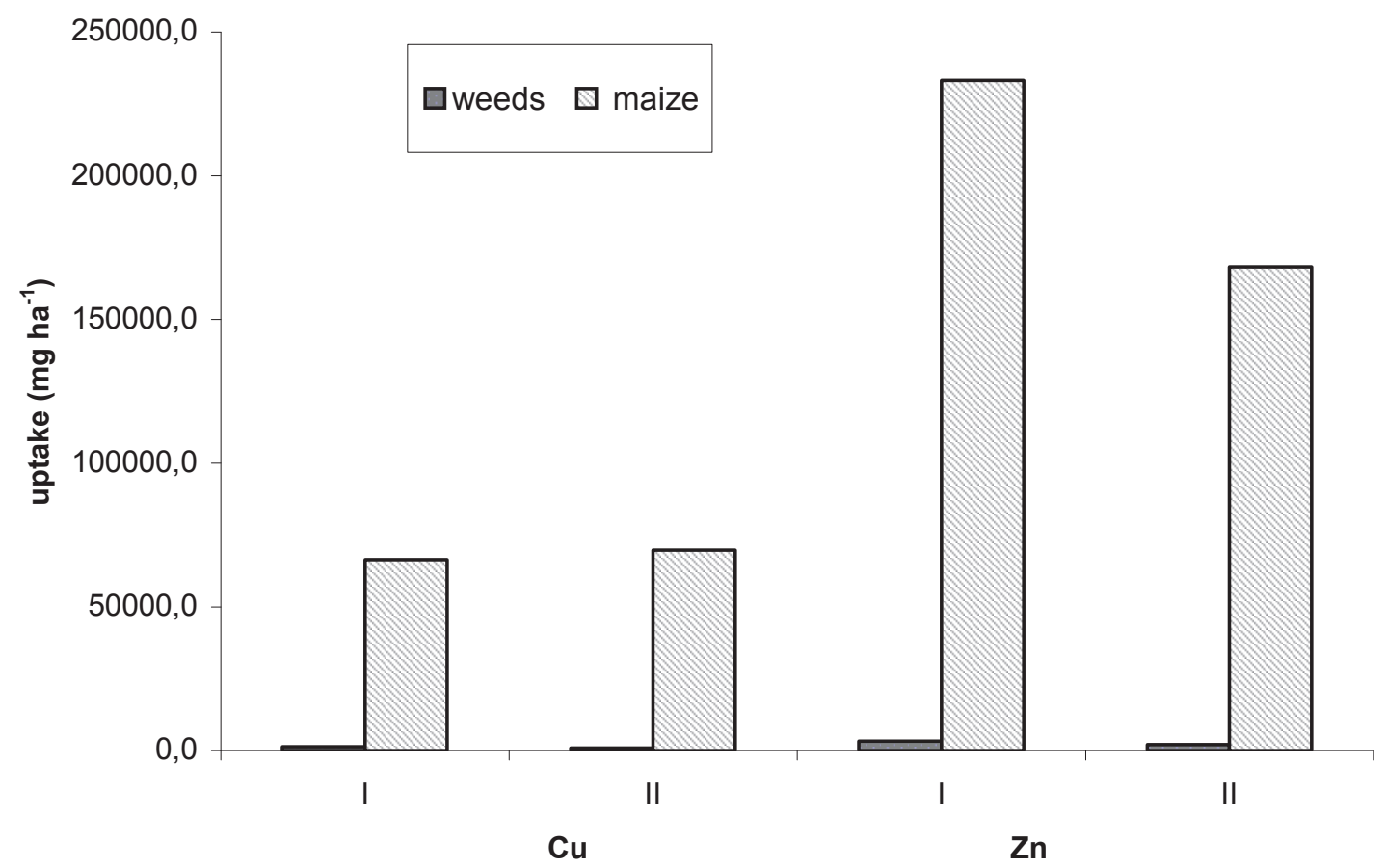

* methods of weed control: I - mechanical, II - chemical

Fig. 1. Total uptake of copper and zinc by maize and weeds depending on the weed control method.

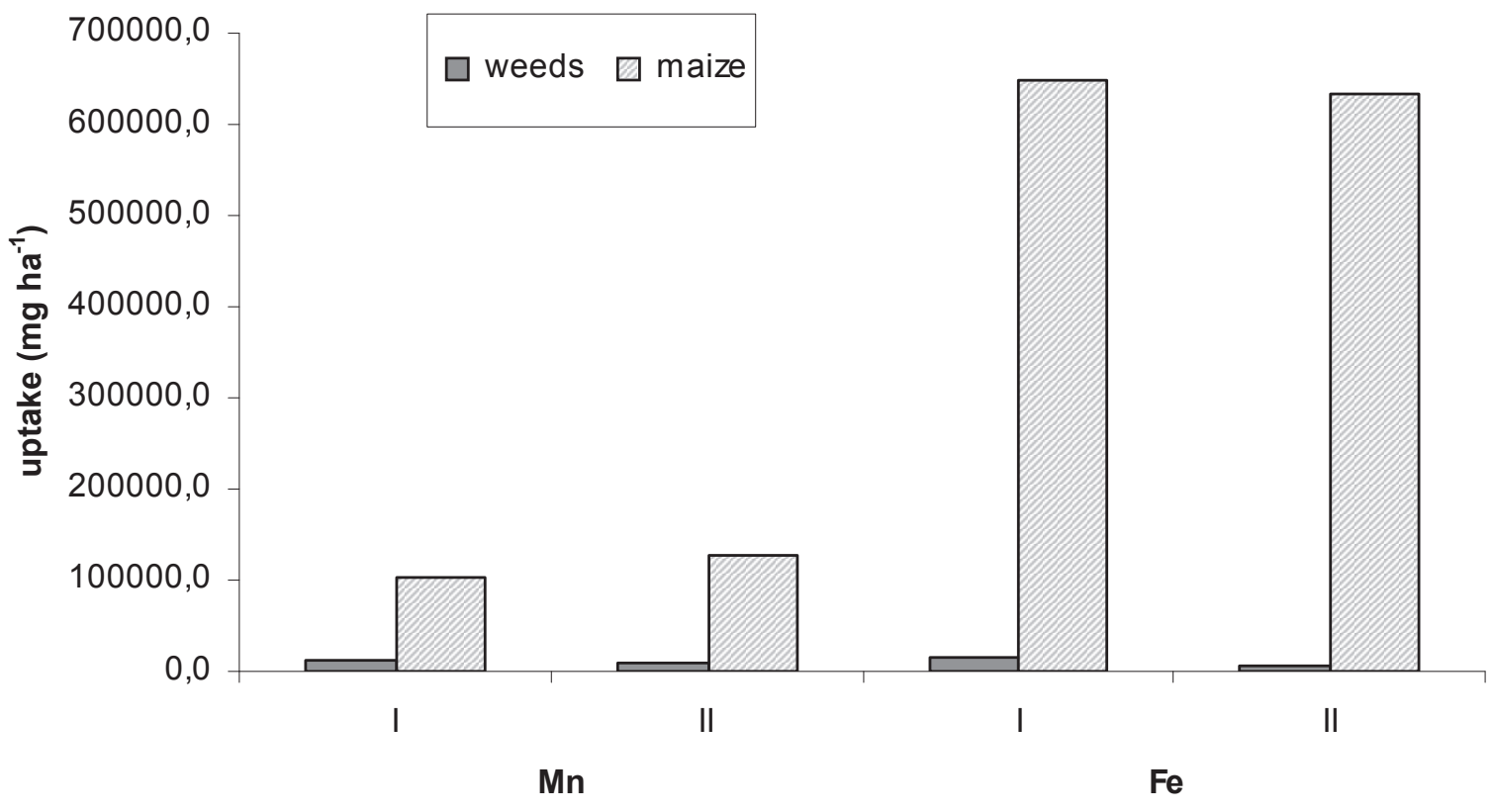

* methods of weed control: I - mechanical, II - chemical

Fig. 2. Total uptake of manganese and iron by maize and weeds depending on the weed control method. 
The value of the species specificity coefficient (SSC) confirms the greater ability of weeds to accumulate copper in comparison with maize (Table 6). With respect to zinc, the lowest value of SSC was for Cirsium arvense $\mathrm{L}$. (0.7). Under conditions of mechanical weed control, maize and the other weed species had a similar value of the species specificity coefficient. On the other hand, in the treatments with chemical weed control, the value of SSC for maize was lower than for segetal species. These differences were due to lower content of zinc in maize when the herbicides were used, in comparison to maize weeded only mechanically. All segetal species had a greater ability to accumulate manganese than maize, especially Chenopodium album L. and Galinsoga parviflora Cav. The calculated SSC coefficient indicates very high potential to accumulate iron by Cirsium arvense L. and substantially lower potential of Chenopodium album L. and Polygonum lapathifolium L. subsp. lapathifolium, similar to that of maize (Table 6).

Table 6

Value of the species specificity coefficient (SSC) for maize and dominant weeds.

\begin{tabular}{|c|c|c|c|c|c|c|c|c|}
\hline \multirow{3}{*}{ Species } & \multicolumn{8}{|c|}{ Microelement } \\
\hline & \multicolumn{2}{|c|}{$\mathrm{Cu}$} & \multicolumn{2}{|c|}{$\mathrm{Zn}$} & \multicolumn{2}{|c|}{$\mathrm{Mn}$} & \multicolumn{2}{|c|}{$\mathrm{Fe}$} \\
\hline & $I^{*}$ & II & I & II & I & II & I & II \\
\hline Echinochloa crus-galli (L.) P. Beauv. & 1.12 & 1.17 & 1.06 & 1.04 & 1.12 & 1.11 & 1.04 & 1.02 \\
\hline Galinsoga parviflora Cav. & 1.11 & 1.09 & 1.02 & 1.03 & 1.57 & 1.60 & 0.81 & 0.82 \\
\hline Chenopodium album $\mathrm{L}$. & 0.90 & 0.91 & 1.06 & 1.01 & 1.58 & 1.62 & 0.55 & 0.56 \\
\hline Cirsium arvense $\mathrm{L}$. & 1.09 & 1.06 & 0.70 & 0.72 & 0.65 & 0.67 & 2.38 & 2.42 \\
\hline Polygonum lapathifolium L. subsp. lapathifolium & 1.03 & 1.08 & 1.13 & 1.10 & 0.91 & 0.92 & 0.56 & 0.57 \\
\hline Zea mays $\mathbf{L}$. & 0.75 & 0.65 & 1.03 & 0.62 & 0.17 & 0.17 & 0.56 & 0.52 \\
\hline
\end{tabular}

Explanation: *methods of weed control: I - mechanical, II - chemical

\section{DISCUSSION}

Maize, due to its cultivation with wide inter-row spacing and its relatively slow growth at the early stages, is quite sensitive to competition from weeds. Weed competitiveness in relation to crop plants varies and it depends on habitat abundance, species and developmental stage, agricultural practices used, and the crop in which weeds occur (R a j can and $\mathrm{Swan-}$ to n, 2001; Chik o ye at al. 2004; Trąba and Wiater, 2007; Rogóż and Kołodziejczy k, 2007; $\mathrm{Gug}$ a $\nmid$ a et al. 2009; G łow a cka, 2011). Chenopodium album $\mathrm{L}$ is one of expansive weeds showing high ability to adapt to habitat conditions (R o l a and R o la, 1996). It usually takes up more minerals than crop plants and its competitive ability depends on soil type, fertilization, crop species, participation in weed infestation and type of nutrient taken up $(\mathrm{Czuba}$ and Wróbel, 1983; Malicki and Berbeciow a, 1986; P a ry lak, 1999; W i ater and Trą ba, 2002; Trąba and Wiater, 2004). In a study by Malicki and Berbeciowa (1986), Cu content in Chenopodium album L. ranged from 6.4 to $13.1 \mathrm{mg}$ $\times \mathrm{kg}^{-1}$ d.w., depending on the crop species among which it grew. Echinochloa crus-galli (L.) P. Beauv., Polygonum lapathifolium L. subsp. lapathifolium and Cirsium arvense L. accumulated much more of this micronutrient. Similarly in our study, among the five dominant weed species in maize Chenopodium album $\mathrm{L}$. accumulated the least $\mathrm{Cu}$. A significantly higher amount of this micronutrient was found in the other taxa, such as Echinochloa crus-galli (L.) P. Beauv., Galinsoga parviflora Cav., Cirsium arvense L., and Polygonum lapathifolium L. subsp. lapathifolium, but the differences between them were negligible. Weeds tend to be more competitive in the uptake of nutrients than crop plants. It certainly depends of the element taken up. Chenopodium album L. and Galinsoga parviflora Cav. can accumulate 4 or 5 times more potassium than maize, while Cirsium arvense L., Chenopodium album L., and Galinsoga parviflora Cav. accumulate up to 10-12 times more calcium than a maize crop in which they grow (G ł o w a c k a, 2011). In the present study, all the weed species tested were also more competitive in the uptake of $\mathrm{Cu}$ than fodder maize. However, these differences were not as high as those reported for macroelements.

The natural content of $\mathrm{Zn}$ in wild plants is between 15 to $80 \mathrm{mg} \times \mathrm{kg}^{-1}$ d.w. (R o g ó $\dot{\mathrm{z}}$ and $\mathrm{Nie}$ $\mathrm{miec}, 2010)$. The competitiveness of weeds in the uptake of $\mathrm{Zn}$ depends on the species and crops in which they appear. The research of M a li c ki and B e r b e c i o w a (1986) showed that Chenopodium album L. is more competitive in the uptake of $\mathrm{Zn}$ than winter wheat and spring barley, and it accumulates this element in a lower amount than sugar beet and spring rape. A similar relationship was also demonstrated in the case of Cirsium arvense L. In our study, regardless of 
the weed control method, Cirsium arvense L. accumulated less zinc than fodder maize. Polygonum lapathifolium L. subsp. lapathifolium was the most competitive in the uptake of this micronutrient.

The manganese content in plants is in a wide range and depends on the characteristics of the species, the content of available nutrient forms in soil and its pH (R o g ó ż and Ni e m i e c, 2010). The concentration of $\mathrm{Mn}$ in maize was on average $10.9 \mathrm{mg} \times \mathrm{kg}^{-1}$ and was significantly lower than that found by $\mathrm{R} \mathrm{a} \mathrm{b} \mathrm{i}$ kowska and Piszcz (2004) and that reported as optimal in animal feed (G o r l a c h, 1991). In this study, the concentration of manganese in all the dominant weed species was significantly higher than in maize. Chenopodium album L. and Galinsoga parviflora Cav. were the species that accumulated the largest amount of manganese. The manganese content in Chenopodium album L. was significantly higher than that obtained by D zid a et al. (2004), similar to that found by Malicki and Berbeciowa (1986) when this taxon occurred in winter wheat, barley and rape, and much lower than that given by $\mathrm{Tr}$ ą $\mathrm{a}$ and $\mathrm{W}$ i a te $\mathrm{r}$ (2004).

Chenopodium album L. and Polygonum lapathifolium L. subsp. lapathifolium accumulated similar amounts of iron as dent maize. Cirsium arvense L. was the species with the highest concentration of this micronutrient. The higher ability of this species to accumulate iron is confirmed by the species specificity coefficient (SSC). The value of SSC higher than 1 indicates the high potential of a given species to accumulate a particular mineral nutrient ( $\mathrm{L} \mathrm{a} \mathrm{m} \mathrm{bert} \mathrm{et}$ al. 1973). The content of Fe recorded in this study for all the dominant segetal species in maize was significantly lower than that reported by other authors $(\mathrm{M} \mathrm{a}$ licki and Berbeciowa, 1986; Rogóż and $\mathrm{Niemiec}, 2010)$.

The quantity of nutrients taken up by weeds is determined more by the size of biomass produced by them than by the content of these components ( $\mathrm{Tr}$ a $\mathrm{ba}$ and Wiater, 2007; G łow acka, 2011). It changes depending on crop rotation or weed control method (Zawiślak and Kostrzewska, 2000; Liszka-Podkowa and Sowiński, 2009). Parylak (1996) reports that the share of weeds in total uptake of potassium may amount to $36 \%$ and of calcium even 56\%. According to $\mathrm{Czuba}$ (2000), the uptake of copper per hectare in maize cultivation is 118 grams. In our study, on average for the experiment, maize took up $68 \mathrm{~g} \mathrm{Cu}$ in biomass produced. This result is similar to that given by $\mathrm{R} \mathrm{a} \mathrm{bi} \mathrm{k} \mathrm{ow} \mathrm{sk} \mathrm{a}$ and P is z c z (2004) who found that maize accumulated $51.6 \mathrm{~g} \mathrm{Cu}$ per hectare. The total uptake of micronutrients by weeds was low and for copper it was $2.1 \%$ and $1.3 \%$, while for zinc $1.46 \%$ and $1.25 \%$ of total uptake by the maize crop. The highest percentage of weeds in total accumulation of micronutrients was obtained for manganese, and it was $9.7 \%$ and $4.8 \%$ for mechanical and chemical methods of weed control, respectively. Such a high percentage was probably due to the low content of manganese in maize and thus it low uptake in plant biomass. On the other hand, iron was the element accumulated in the highest amounts by maize and its accompanying weeds.

\section{CONCLUSIONS}

1. All the weed species tested contained more copper than the maize plants in the biomass. The zinc content in maize and segetal species was similar, with the exception of Cirsium arvense L. which took up much less of this nutrient.

2. The ability to uptake manganese and iron shows high species specificity. Chenopodium album L. and Galinsoga parviflora Cav. accumulated more manganese, while Cirsium arvense L. exhibited much higher capacity to accumulate iron than maize and the other weed species.

3. The ability of the dominant weeds to accumulate micronutrients varied and depended on the species and element, but their percentage of total uptake of $\mathrm{Cu}, \mathrm{Zn}, \mathrm{Mn}$ and $\mathrm{Fe}$ by the maize crop was generally low.

4. Echinochloa crus-galli (L.) P.Beauv was the weed species that took up the highest amount of nutrients due to its quantitative dominance.

\section{Acknowledgements}

Research supported by the Ministry of Science and Higher Education of Poland as the part of statutory activities of Department of Soil and Plant Cultivation, University of Life Science in Lublin.

\section{REFERENCES}

Chikoye D., Schulz S., Ekeleme F. 2004. Evaluation of integrated weed management practices for maize in the northern Guinea savanna of Nigeria. Crop Protect. 23: 895-900. http://dx.doi.org/10.1016/j.cropro.2004.01.013

Czuba R. 2000. Mikroelementy we współczesnych systemach nawożenia. / Trace elements in modern systems of fertilization. Zesz. Prob. Post. Nauk Rol. 471: 161-169 (in Polish).

Czuba R., Wróbel S. 1983. Ocena roli chwastów jako konkurentów w pobieraniu składników pokarmowych przez rośliny uprawne. / Evaluation of the role of weeds as competitors in nutrient uptake by crop plants. Rocz. Gleb. 34(3): 175-184 (in Polish). 
Duer I. 1986. Skład chemiczny chwastów oraz pobranie składników mineralnych przez chwasty i zboża w zmianowaniach z różnym udziałem zbóż. / Chemical composition of weeds and nutrient uptake by weeds and cereals in rotations with different percentages of cereal crops. Pam. Pul. 88: 191-204. (in Polish)

Dzida M., Furmanek T., Podsiadło C. 2004. Wpływ chwastów segetalnych na kumulację metali ciężkich w jęczmieniu jarym. / Effect of segetal weeds on accumulation of heavy metals in spring barley. Roczniki AR w Poznaniu, CCCLXIII: 61-68. (in Polish)

G łowacka A. 2007. Wpływ współrzędnej uprawy pasowej na zachwaszczenie kukurydzy pastewnej. / Effect of the strip intercropping system on weed infestation in maize. Acta Agrophys. 10(3): 573-582. (in Polish)

Głowacka A. 2011. Dominant weeds in maize (Zea mays L.) cultivation and their competitiveness under conditions of various methods of weed control. Acta Agrobot. 64 (2): 119-126.

Gorlach E. 1991. Zawartość pierwiastków śladowych w roślinach pastewnych jako miernik ich wartości. / The content of trace elements in fodder plants as a measure of their values. Zesz. Nauk. AR w Krakowie, 262: 13-21. (in Polish)

Gugała M., Zarzecka K., Mystkowska I. 2009. Pobranie wapnia i magnezu przez chwasty w łanie ziemniaka w warunkach zróżnicowanej agrotechniki. / Uptake of calcium and magnesium by weeds in a potato canopy under different cultivation practices. Ann. UMCS, sect. E, LXIV(3): 41-49. (in Polish)

Lambert J., Denudt G., Van Oudenhove C. 1973. Aspects ecologiques et phytosociologique de l'analyse des herbages. Rev. Agric. 4: 893-908. (in French)

Liszka-Podkowa A., Sowiński J.2009. Skuteczność różnych metod odchwaszczania kukurydzy oraz pobranie mikropierwiastków przez chwasty. / Efficacy of different methods of weed control in maize and macronutrient uptake by weeds. Fragm. Agron. 26(3): 109-117. (in Polish)

Malicki L., Berbeciowa Cz. 1986. Uptake of more important mineral components by common field weeds on loess soil. Acta Agrobot. 39(1): 129-141.

Oświt J., Sapek B. 1982. Ocena zawartości składników mineralnych $\mathrm{w}$ roślinach łąk naturalnych i zdolność gatunków do wykorzystania zasobów glebowych. / Estimation of nutrient content in natural meadow plants and the ability of species to use soil resources. Rocz. Glebozn. 33: 145-150. (in Polish)

Parylak D. 1996. Konkurencyjne pobieranie składników pokarmowych przez jęczmień jary i chwast. / Competitive uptake of nutrients by spring barley and weeds. Frag. Agronom. 4(52): 68-74. (in Polish)

Parylak D. 1999. Zmiany konkurencyjności chwastów w pszenżycie jarym pod wpływem nawożenia mineralnego. / Changes in competition between weeds and spring triticale under the influence of mineral fertilization. Prog. Plant Protect./Post. Ochr. Rośl. 39(2): 683-685. (in Polish)
Parylak D., Zawieja J. 2004. Wpływ zagęszczenia łanu na zmiany konkurencyjności jęczmienia jarego i owsa głuchego (Avena fatua L.) w zakresie pobierania mikroelementów. / The effect of standing crop density on changes in competitiveness of spring barley and wild oats (Avena fatua L.) for microelements uptake. Zesz. Prob. Post. Nauk Rol. 502, cz. II: 935-943. (in Polish)

Qasem J.R., Hill T.A. 1995. Growth, development and nutrient accumulation in Senecio vulgaris L. and Chenopodium album $\mathrm{L}$. Weed Research 35: 87-196. http:// dx.doi.org/10.1111/j.1365-3180.1995.tb02032.x

Rabikowska B., P iszcz U. 2004. Wpływ zróżnicowanego nawożenia azotem na wykorzystanie miedzi, manganu i cynku z obornika w czteroletnim zmianowaniu. Cz. I. Miedź. / Effect of differentiated nitrogen fertilization on utilization of copper, manganese and zinc of FYM in 4 year crop rotation. Part I. Copper. Zesz. Prob. Post. Nauk Rol. 502, cz. I.: 267-275. (in Polish)

Rajcan I., Swanton C. J. 2001. Understanding maizeweed competition: resource competition, light quality and the whole plant. Field Crops Research 71: 139-150. http://dx.doi.org/10.1016/S0378-4290(01)00159-9

Rogóż A., Kołodziejczyk P. 2007. Zawartość pierwiastków śladowych w chwastach roślin zbożowych na tle ich zawartości w glebie. Cz. I. Zawartość $\mathrm{Cu}, \mathrm{Zn}$ oraz Mn w glebie i w chwastach. / Trace element content in cereal crop weeds against the background of their content in soil. Part I. Content of $\mathrm{Cu}, \mathrm{Zn}$ and $\mathrm{Mn}$ in soil and weeds. Zesz. Prob. Post. Nauk Rol. 520: 685-694. (in Polish)

Rogóż A., Niemiec M. 2010. Zawartość pierwiastków śladowych w chwastach roślin zbożowych na tle ich zawartości w glebie. / Contents of trace elements in weeds of cereal crops against the background of their contents in soil. Zesz. Prob. Post. Nauk Rol. 556, cz. II.: 907-922. (in Polish)

Rola J., Rola H. 1996. Ekspansywne chwasty segetalne w uprawach rolniczych w Polsce. / Expansive segetal weeds in arable crops in Poland. Zesz. Nauk. ATR Bydgoszcz, Rolnictwo 196(38): 17-22. (in Polish)

Trąba C., Wiater J. 2004. Zawartość i pobranie niektórych mikroelementów przez komosę białą w zależności od rośliny uprawnej i nawożenia odpadami. / The content and uptake of selected microelements by pigweed (Chenopodium album L.) depending on cultivated plant and fertilization with wastes. Zesz. Prob. Post. Nauk Rol. 502: 1011-1021. (in Polish)

Trąba C., Wiater J. 2007. Reakcja Chenopodium album na rodzaj nawożenia i gatunek rośliny uprawnej. / The reaction of Chenopodium album to the kind of manuring and crop species. Ann. UMCS, sect. E, LXII (2): 23-32. (in Polish)

Wiater J., Trąba C. 2002. Konkurencyjność pokarmowa chwastów wobec ziemniaka w warunkach następczego wpływu odpadów. / The nutritive competition of weeds as compared to potato in sequent influence of wastes. Acta Agrophys., 73: 327-337. (in Polish) 
Yin L., Cai Z., Zhong W. 2006. Changes in weed community diversity of maize crops due to long-term fertilization. Crop Protect. 25: 910-914. http://dx.doi. org/10.1016/j.cropro.2005.11.013

Zawiślak K., Kostrzewska M. 2000. Konkurencja pokarmowa chwastów w łanach żyta ozimego uprawianego w płodozmianie i w wieloletniej monokulturze. II. Zawartość i pobranie makroelementów w nadziemnej biomasie żyta ozimego i chwastów. / The nutritional competition of weeds in winter rye crops grown in crop rotation and long-term monoculture. II. Macronutrient content and uptake in above-ground biomass of winter rye and weeds. Ann. UMCS, sect. E, LV, suppl. 33: 269-275. (in Polish)

\section{Zawartość oraz pobranie mikroelementów (Cu, Zn, Mn, Fe) przez kukurydzę pastewną (Zea mays L.) oraz towarzyszące chwasty}

\section{Streszczenie}

Eksperyment polowy przeprowadzono w latach 2008-2010, w Stacji Doświadczalnej Wydziału Nauk Rolniczych, Uniwersytetu Przyrodniczego w Lublinie. Rośliny rosły na glebie brunatnej, o odczynie lekko kwaśnym oraz średniej zasobności w miedź, cynk, mangan i żelazo. W doświadczeniu założonym w układzie losowanych podbloków, w czterech powtórzeniach uwzględniono dwie metody regulacji zachwaszczenia kukurydzy: I. mechaniczna - dwukrotne opielanie międzyrzędzi; II. chemiczna - herbicyd Afalon Dyspersyjny 450 EC bezpośrednio po siewie (s.a. linuron, $\mathrm{w}$ dawce $900 \mathrm{~g} \times \mathrm{ha}^{-1}$ ).

W kukurydzy i dominujących gatunkach chwastów oznaczono zawartość miedzi, cynku, manganu i żelaza. Wyliczono również pobranie składników z 1 ha oraz współczynnik specyfiki gatunkowej (WSG). Wszystkie badane gatunki chwastów zawierały w biomasie więcej miedzi niż kukurydza, ale ich udział w całkowitym pobraniu mikroelementu był niewielki, średnio 1,7\%. Zawartość cynku w biomasie kukurydzy i gatunkach segetalnych była zbliżona, z wyjątkiem Cirsium arvense L., który gromadził znacznie mniej cynku niż kukurydza oraz pozostałe taksony chwastów. Pobranie cynku przez dominujące gatunki chwastów stanowiło tylko 1,4\% ogólnego pobrania mikroelementu przez łan kukurydzy. Konkurencyjność chwastów w kumulacji manganu i żelaza wykazywała dużą specyfikę gatunkową. Chenopodium album L. i Galinsoga parviflora Cav. były najbardziej konkurencyjne w gromadzeniu manganu, zaś Cirsium arvense L. wykazał dużą zdolność do akumulacji żelaza, znacznie większą niż kukurydza oraz pozostałe gatunki chwastów. Udział chwastów w całkowitym pobraniu manganu był stosunkowo duży i wynosił średnio dla doświadczenia $7,2 \%$. 
